\title{
Who Wants to be a Millionaire? Gendered Entrepreneurship and British South Asian Women in the Culture Industries
}

Qui veut gagner des millions? L'entreprenariat des femmes britanniques d'Asie du sud dans les industries de la culture

¿Quién quiere ser millonaria? El empresariado de mujeres británicas de Asia del sur en las industrias de la cultura

\section{Dipannita Basu et Pnina Werbner}

\section{OpenEdition}

\section{Journals}

Édition électronique

URL : https://journals.openedition.org/remi/4984

DOI : 10.4000/remi.4984

ISSN : $1777-5418$

Éditeur

Université de Poitiers

Édition imprimée

Date de publication : 1 décembre 2009

Pagination : $53-77$

ISBN : 978-2-911627-53-8

ISSN : 0765-0752

\section{Référence électronique}

Dipannita Basu et Pnina Werbner, « Who Wants to be a Millionaire? Gendered Entrepreneurship and British South Asian Women in the Culture Industries », Revue européenne des migrations internationales [En ligne], vol. 25 - n³ | 2009, mis en ligne le 01 décembre 2012, consulté le 15 avril 2022. URL : http:// journals.openedition.org/remi/4984; DOI : https://doi.org/10.4000/remi.4984 


\title{
Who Wants to be a Millionaire? Gendered Entrepreneurship and British South Asian Women in the Culture Industries
}

\author{
Dipannita BASU* and Pnina WERBNER ${ }^{* *}$
}

\section{INTRODUCTION: IMAGES OF SOUTH ASIAN WEALTH ${ }^{1}$}

A cursory examination of the images of British Asian millionaires and multimillionaires appearing in the annual Eastern Eye magazine, The 200 Richest Asians in Britain (2001, 2002, 2003), provides a clue to understanding popular media representations that naturalise notions of individual business success and their gendered inflections. Against this backdrop, we propose in the present paper that British Asian millionaires are merely the tip of an 'entrepreneurial iceberg'; that in order to understand their rise, we need to look beneath that visible tip to the myriad of interconnected small ethnic businesses (SMEs) and self-employed entrepreneurs concentrated within an ethnic enclave economy or sector. According to this tip-of-the-iceberg theory, 'success' disguises SME sectoral concentrations, creating the illusion that entrepreneurship is individual, rather than a collective phenomenon. This is reflected in gendered representations of entrepreneurship that stress its masculine, epic, individualistic, risk-taking characteristics, while routinely ignoring or trivialising the role of women in businesses. Women are depicted as a minor part of family enterprises, often filling a shadowy, behind-the-scenes supporting role. As some larger firms have expanded and gone public, however, it is evident that wives and children are being visibilised as co-directors and that women entrepreneur millionaires are emerging in their own right.

\footnotetext{
* Professor in Sociology and Black Studies at Pitzer College, Claremont, California; dipa_basu@ pitzer.edu

** Professor of Social Anthropology School of Social Relations, Keele University, Keele, Staffs. ST55BG; p.werbner@keele.ac.uk

1 This paper was first presented at a EURESCO-funded conference on Ethnic business in Europe and America, held in Spain in October 2000. We would like to thank participants at the conference and anonymous reviewers for their very useful comments.
} 
In Britain's Richest Asians magazines, the language deployed is of tough competition, of building, strategy, and rivalry. Verbs of power and force, along with spatial images of global mastery, are clearly part of the English language journalese for tycoonery and outstanding economic success. The playing fields of wealth are as competitive, it is implied, as the football grounds of Old Trafford or Wembley, and as imperially expansive as those of Eton or Harrow. They are also as exclusive. The millionaire club is, it would appear from the pictures and accounts, a club of outstanding individuals, men who made it by being remarkably smart and prescient, hard-working and bold. Many key metaphors used by the magazine to describe the millionaires are thus taken from the field of competitive sport, while others draw on the language of imperial conquest and war. Entrepreneurs are 'major forces' building 'major empires.' They 'leave competitors in the dust,' 'race ahead,' 'conquer (...) around the world.' Lakshmi Mittal, one of the richest men in Britain, is described as a media 'mogul' who has teamed up with 'heavyweights'; a 'serious player' who achieved a 'coup'. The effect of this language is to define business success as a male achievement. One successful millionaire, Dinesh Damija, 50, whose wife is, incidentally, in charge of the day-to-day running of the business, is said to have turned his internet site into a 'European Powerhouse.' Playing a 'different game,' he is now 'moving into cyberspace and hoping to conquer Europe'. ${ }^{2}$

A cursory look at the images of female success in the same period reveals that most are couched in familial terms, as a domestication of the public realm. 'She also raised four children', 'with the support of the family'. A successful food millionaires is the 'Samosa Queen'. In the 2003 magazine, the cover story, 'The Young Ones: Meet the Next Generation of British Asian Entrepreneurs', featured one woman and five men. In the 2000 Eastern Eye magazine, out of the 200 ranked richest South Asian millionaire firms, only 16 were women-owned. These included 12 husband-and-wife teams, one brother-andsister team and three independent women, one a widow who appeared to have taken over the family business. Out of the husband-and-wife teams, six were in the food industry, with wives clearly key figures: Meena Pathak from Blackburn (ranked 28th), a major producer of spices and chutneys, Mrs. Warsi of Derby (ranked 36th), Kamal Basran of Stockport (ranked 116th), both packaging Asian food for supermarkets, play key roles in food manufacturing. So too does Bobby Dhillon, 31, in the property and leisure markets. Along with her brother Tej she set up a chain of London hotels, and is described in the magazine as talking business in hospital, just after giving birth to her first child (p. 23)!

The imagery of wealth and success thus continues the narrative association of women in business with domesticity, human nurturing and reproduction, even for those who appear to have broken away from their traditional role of behind-the-scenes 'little helpers'. Thus, for example, of the 163 firms headed by older males, 62 (40 per cent), are described as 'family' firms. Behind the male façade, the oldest South Asian immigrant firms in Britain are by now intergenerational, and in some, wives and daughters play an important role barely mentioned by the magazine. In particular, hidden from view is that fact that South Asian women in Britain also act as independent individual entrepreneurs who, like their male counterparts, take cultural risks and face internal and external barriers and opportunities in the expanding South Asian 'brown' immigrant ethnic economy (Thandi, 2006).

2 These particular images are taken from the 2000 issue.

REMI 2009 (25) 3 pp. 53-77 
At the top of the list of the richest South Asians in Britain, the billionaires clearly come from large trading families. Clearly also, some of the prominent South Asian firm owners received a superior education - like the millionaire with a Cambridge degree who started a bucket shop travel agency some 25 years ago, buying unused tickets from airlines, and is now set to 'conquer' Europe with his internet site and chain of agencies. There are undoubtedly some outstanding individuals among the multi-millionaires listed in the Asian 2000 magazine. But their achievements, we propose, are often a culmination of what Light and Rosenstein have called 'entrepreneurial movements' (1995: 4). 'In many cases', these authors argue, 'innovations have been the product of an entrepreneurial movements whose members were individually unknown' (ibid.). This is particularly so, they note, in the case of the growth of the fast food industry responsive to the rapid rise of new food consumption habits during the twentieth century.

\section{BRITISH SOUTH ASIAN ETHNIC ENCLAVE ECONOMIES}

A cursory glance at the UK Census 2001 reveals that while there are 15,003 Asian men in the category of 'Business and Public Service Professionals', ${ }^{3}$ there are also 7,933 women in this category, more than a third. ${ }^{4}$ Among 'Business and Associate Service Professionals' there are 18,926 Asian men $^{5}$ and 13,759 women. ${ }^{6}$ Thus the presence of women as well as men in business and professional activities is significant. ${ }^{7}$ This is where it also becomes important to focus on an affluent cohort of Asians who do not appear on the magazine's Richest South Asians in Britain 200 list. As the census discloses, these are the self-employed high-earning professionals: doctors (who work privately as well as for the NHS), dentists, accountants, opticians, pharmacists, as well as those in the leisure, cultural and media industries and sectors. So too, Dhaliwal reports that wealth creation in new economy sectors such as IT, Media and the Internet increased by over $£ 690$ million in the eight years to 2005 (Dhaliwal, 2006b).

South Asians immigrants in Britain tend to concentrate in particular sectors of the economy (Dhaliwal and Adcroft, 2005). Historically, the scholarly gaze in British research on South Asian entrepreneurship has shifted from studying only the most visible businesses (such as Muslim halal groceries or Indian restaurants, sari and jewellery shops) located in ethnic-specific sectors and neighbourhoods, to researching non-culturally specific South Asian businesses, often spatially dispersed, which are nevertheless concentrated in particular industries or sectors. Among these non-ethnic specific sectors, the historical entry of women into the media and cultural industries has received little recognition so far.

3 10,565 Indians, 3,471 Pakistanis and 967 Bangladeshis. Metcalf et al. (1996) suggest that Muslim entrepreneurs may be more motivated to enter business because of racism than other Asians.

4 6,135 Indians, 1,388 Pakistanis and 410 Bangladeshis.

5 13,335 Indians, 4,546 Pakistanis and 1,045 Bangladeshis.

6 10,847 Indians, 2,310 Pakistanis and 602 Bangladeshis.

7 In her report to Barclays, Dhaliwal (2006b) says that 'wealth generated by Asian women within the top 200 more than quadrupled between 1998 and 2005, with the number of women listed within their own right doubling within the same period.' 
Analysing the clothing and textile enclave economy in Manchester, in her book and a series of articles Werbner has highlighted the centrality of credit networks and flows, and supply lines between importers, wholesalers, manufacturers, market traders and homeworker machinists (Werbner, 1990/2002). She follows Lefebvre's theorisation of networked space as socially produced and meaningfully constructed (Lefebvre, 1991; Werbner, 2001: 674). Rather than territorially circumscribed, Lefebvre (1991: 77) argues that social spaces contain:

\section{'(...) the networks and pathways which facilitate the exchange of material things and information. Such 'objects' are not only things but also relations. As objects, they possess discernible peculiarities, contour and form. Social labour transforms them, rearranging their positions within spatio-temporal configurations (...).'}

Social spaces interpenetrate, intertwine and overlap, attaining 'real' existence 'by virtue of networks and pathways, by virtue of bunches or clusters of relationships' (Lefebvre: 86; 88). Multiple, overlapping markets 'attain their concrete form by means of a network' embodied materially in city scapes and structures (p. 86). Yet 'they retain their distinctiveness' (p. 342) through distinctive chains of commodities which may be conceived of as 'formants' of space (p. 342) activated by human labour.

Also on the clothing industry, Ram studied labour relations in Asian-based clothing manufacturing firms in the Midlands (Ram, 1994). Women barely figured in these studies, except as low-paid manual workers, but more recently, a fine-grained study of ethnic-specific British South Asian women fashion designers and entrepreneurs, by Bhachu (2004), describes networks of supply from India through importers, local boutiques and designers, mini-bazaars and home-based, tupperware-style sales. Similarly, Raghuram (2003) has analysed the career of a single successful Asian woman entrepreneur, designing and selling Asian fashion.

Research has also focused on key features and dilemmas of recruitment and interfirm relationship: enclaves economies tend to differ according to class, and sometimes ethnic background. Ram and Carter's study of accountants (2003) is outstanding in that it considers the accelerating move of South Asians into professional occupations along with their continued embeddedness in intra-ethnic business networks and interdependencies, and the difficulty they have encountered in breaking out into a wider market. Other sectoral studies include a study of Gujarati Patel newsagents (Lyon and West, 1995), taxi drivers and takeaways (Kalra, 2000), and 'Indian' restaurants, mostly owned by Bangladeshi immigrants in Britain (Jones, Abbas and Ram, forthcoming). A limitation of this latter study is that, while analysing the expansion of some firms into chains, it provides no hint on the intra-ethnic firm networks in which such restaurants are embedded. Nor do women figure in any of these studies.

Within certain South Asian economic and commercial sectors in the UK, a large proportion of wealth is commanded by smaller businesses. This is reflected in Dhaliwal and Adcroft's (2005) sector-based analysis of the Top 200 Asians in the Annual Asian UK wealth index. The index, they note, displays some interesting shifts in the balance of wealth, from the dominance of manufacturing and retailing, to sectors such as fashion, textiles, IT, Media and Internet. Importantly, Dhaliwal and Adcroft argue that: 
'(...) the Asian wealth creating sector is not overly reliant on just a few stellar performers. For example, since 1998, the top 10 per cent of Asian wealth creators have accounted for a diminishing proportion of total wealth generated; whilst almost two-thirds of Asian wealth was generated by the top 20 performers in 1998, by 2004 this proportion had fallen to under a half. Despite the proportionate fall in

the contribution of these elite wealth creators, the point should not be lost that in 2004 the top 10 per cent accounted for almost $£ 900$ million more wealth than seven years previously. This suggests that the general British economic problem of slow growth is not one seen in this element of the ABS and this conclusion is reinforced through further examination of key components of this wealth creation.'

(2005a: 10; see table in Appendix 1)

Another way of reading the annual Eastern Eye list of Asian millionaires, then, is to recognise that while certain individuals may be more effective entrepreneurs than others, their success is the product of embeddedness in ethnic industrial clusters or ethnic enclave economies. ${ }^{8}$ In many cases they have grown their businesses - wholesaling, importing or manufacturing - as new South Asian SMEs have followed them into a particular niche. It is this approach which we want to develop here, as we have in a series of earlier books and articles (Werbner, 1987, 1990a, 1990b, 1999, 2001; Basu and Werbner, 2000), by problematising, in this instance, the issue of gender and generation.

Though the statistics point to a hidden dynamic, on the whole little attention has been devoted in the study of so-called economic sectors to processes of recruitment and expansion of such ethnic enclave economies, for example through the extension of intraethnic credit between more established and newly formed firms, or - apart from more generalised discussions of how initial financing is obtained - how South Asian generational transfer of cultural capital, which leads to the expansion of a sector or industry, is achieved in practice. This is a key topic of the present paper.

A significant advance in this regard are studies of the succession challenges facing South Asian family firms (Bachkaniwala, Wright and Ram, 2001; Janjuha-Jivraj and Woods, 2002; Junejo, 2005; Dhaliwal, 2000). These stress the mediatory role of mothers (Janjuha-Jivraj, 2004), often widows, and the complexity of labour and gender relations within the family firm (Baines and Wheelock, 1998). In particular, Janjuha-Jivraj (2004) has explored the dynamics, involvement and subsequent impact of mothers as a critical buffer between (male) generations experiencing transition. Despite these studies, however, there is little on sectoral development as successive generations gain cultural capital: ${ }^{9}$ how do small firms 'break out' of a particular enclave, for example the cheap end of the fashion trade or ethnic-specific markets, into higher quality or less ethnically dominated and hence more lucrative markets? Although notions of cultural capital and ethnic networks are conceptually useful (Janjuha-Jivraj, 2003), few studies consider social network organisation within an industry, defined horizontally and vertically in terms of

8 Underlining the extent of growth in the Asian sector, the top 10 per cent now account for almost as much wealth as the combined total of the top 200 businesses in 1998, according to a recent report by Spindler Dhaliwal commission by Barclays Business press release (Dhaliwal, 2006b).

9 Though see the somewhat ambiguous findings of Janjuha-Jivraj and Woods, 2002. 
chains of suppliers and vectors of exchange (of know-how, credit) or of competition (on these see Werbner, 1990a/2002).

Despite the recognition that South Asian immigrant businesses are concentrated in identifiable sectors, and that these sectors have undergone processes of expansion and diversification, there are thus still many lacuna in sectoral analysis beyond the ethnicspecific sector catering to the consumption demands of fellow co-ethnics. For example, taxi driving, an expanding industry dominated by Pakistanis, is yet to be studied in depth (Kalra 2000's study focuses - like other such studies - on personal and cultural motivations for entering this trade). Neglected also are in-depth studies of the property market, pharmaceuticals, hotels, IT, and food manufacturing. There remains, then, a need for much more industry/sector-specific research on Asian business.

\section{INDIVIDUAL ENTREPRENEURS VERSUS ETHNIC ENCLAVE ECONOMIES}

The individual entrepreneur has always been the subject of extreme fascination in economic theory. Invariably, 'he' is described as a male actor. Schumpeter believed that only 'one man or a few men had the vision to become entrepreneurs (Schumpeter, 1991: 413, cited in Light and Rosenstein, 1995: 3, emphasis added). In an early anthropological attempt to theorize entrepreneurship, Barth argued that the entrepreneur seeks to maximize returns within a niche by utilizing his particular assets (Barth, 1963: 9, emphasis added). The niche is both constraining and enabling for the entrepreneur, an individual innovator:

'The essence of entrepreneurial activity is to discover new possible channels and exploit them; to enter such a system in which value flows and expand it, short-circuit it, or otherwise make it flow differently, while tapping or otherwise accumulating some of the flow in the form of profit. '(Barth, 1963: 12) argue that:

In a critique of prevalent elite theories of entrepreneurship Light and Rosenstein

'Traditional entrepreneurship's elitism yields a great man theory of economic history as bankrupt as the great man theory of political history (...). The important differences between rich and poor entrepreneurs usually reflect the level at which each entered the business system rather than each one's innovation or business acumen.' 'Light and Rosenstein, 1995: 4, emphasis added)

Despite the stress on the unique qualities of the individual entrepreneur, psychological attempts to theorise the kind of qualities innovative individuals of this type might possess have, the authors argue, mostly failed (ibid.: 2). Elsewhere Light argues that the differential success of immigrant businessmen must be sought in the prior class as well as collective ethnic and cultural resources of immigrant entrepreneurs (e.g. Light, 1984). Prior capital, whether financial, cultural, class or ethnic, is thus a key determinant in Light's model of entrepreneurial success. 
Although Light does not address the issue of gender explicitly, in other respects his stress on social and cultural capital seems to be supported by the South Asian millionaire rankings in Britain.

\section{INDUSTRIAL CLUSTERS AND ETHNIC ENCLAVE ECONOMIES}

The notion of an 'ethnic enclave' echoes Barth's notion of the 'niche' and Light and Rosenstein's of entrepreneurial movements in relation to a more detailed and elaborate theory of industrial development. Elsewhere (Werbner, 2001), Werbner has shown in detail the parallels between ethnic enclave economy theories and recent theories of SME (Small and Medium Enterprise) industrial clustering as these are spelled out by Schmitz and Nadvi (1999).

Briefly speaking, ethnic enclave economies are a particular instance of industrial clustering which catches up a large number of co-ethnic businessmen in a single economic network. Despite a critique of the concept, the ethnic enclave economy (as distinct from the 'ethnic economy' or 'niche') may be defined - much as industrial clusters have been defined - as a networked cluster of ethnic firms producing particular goods, along with the connected ethnic firms supplying and servicing the cluster. The triadic relation generating an ethnic enclave economy is person/good/networked space. Ethnic enclave economies may be localised or dispersed: in Manchester, the Asian residential cluster, the Asian clothing wholesale cluster and the Asian commercial and restaurant cluster are located in different places. The enclave may involve several different ethnic groups positioned differentially in the supply line. It is characterized by cut-throat horizontal competition, as well as by circles of credit and trust.

\section{THE CLUSTERING OF SOUTH ASIAN BUSINESS IN BRITAIN}

This is reflected in representations of the 200 richest South Asians in Britain. Exceptional are global manufacturers of steel, plastics, electronics and heavy industry, many of whom had prior stakes in industries which now have a global reach, such as plantations in the developing world or steel plants in Indonesia or the US. Their owners have settled in London but they may just as well have chosen to live elsewhere. Several have expanded into the media on a large scale - through major TV and cable networks, leisure theme parks and the internet.

Most Asian multi-millionaires, especially in the over-40s cohort, are, however, concentrated in the kinds of industries to which Asian immigrants were traditionally attracted in Britain, and in which there exist also a multitude of small and medium sized firms. Out of the 167 over-40s firms, there are 38 in fashion, textile and yarn. These are widely scattered, with clear concentrations in London, Birmingham, Leicester, Manchester and Glasgow, where Asian ethnic enclave fashion economies are prominent. The millionaire firms are the major wholesalers, importers and British chain retailers (such as 'New Look') in these cities. Few are manufacturers, yet at the grassroots level, it is in manufacturing along with market trading and petty retailing that most Asians in the clothing industry historically concentrated. 
There are 37 firms in the food industry (seven are shareholders in a single firm, Bestways). Millionaires are concentrated in cash and carry or importing, but noticeable also is the exceptional growth of some food manufacturing firms, supplying not just the thousands of Asian delicatessen and restaurant owners who form the 'base' of the enclave, but supermarkets as well. It is in this field, that an 'entrepreneurial movement' has created a cultural revolution in British eating habits, and select Asian food manufacturers have benefited from it.

Other obvious concentrations are in leisure and hotels - including travel agencies (15), pharmaceuticals (11, four in one firm, Goldshield, a pharmaceutical marketing company). These too are areas in which South Asian immigrant entrepreneurs have invested heavily in SMEs. Linked to the leisure and hotel sector are major property investors. On a much smaller scale, however, property investment, mainly for rental, is widespread among South Asians in Britain, who often manage several rental properties while simultaneously holding a regular job (Werbner, 2001).

For some British Asian entrepreneurs, their 'ethnicity' or cultural-specific capital may be a less prominent feature of their business investment strategies than in previous generations. This is indicated by the new concentrations of younger South Asians in computers and IT. At the same time, ethnically specific resources are refashioned to break out of local markets, to create and meet regional, national and international demand. Bhachu (2004) focuses on the transformation of negatively coded ' 70 s ethnic' shalwar kamiz into a global fashion garment. Entrepreneurial activities of innovative second-generation British South Asian women designers have turned traditional clothing into a new aesthetics, which not only redefines Asian and British identities, but enables British South Asian women on the margins to intervene in the processes of global capitalism. Their success illustrates the fact that while fashion is still an attractive option for Asian businesses, the move is towards more designer-conscious clothing, including 'ethnic' clothing, away from the cheaper end of the market where the older generation concentrated. With this comes a shift from a singular stress on masculinity and the dominance of men in the enclave. It is this shift which we wish to explore further through a more detailed study of the entry of South Asian women into the media and culture industries in Britain.

\section{THE RISE OF SOUTH ASIAN WOMEN IN THE MEDIA}

In 1999, The Asian Women of Achievement Awards was founded to recognize the accomplishments and contributions that Asian women have made to the wider society in the United Kingdom. ${ }^{10}$ Commenting on the Awards and past winners, Patron Cherie Booth (the wife of then Prime Minister Tony Blair) noted that 'Asian women are injecting energy into communities, bringing new qualities to the world of business, introducing fresh thinking to the arts' (http://www.redhotcurry.com/Archive/news/2002/awa2002 winners.htm).

10 The award was the brainchild of a successful South Asian businesswoman and author, Pinky Lilani, and is sponsored by major corporations, with several categories of awards: performing arts, arts, music and creative writing, management and innovators.

REMI 2009 (25) 3 pp. 53-77 
Meera Syal, a prominent actress in films (Sammy and Rosie Get Laid and Bhaji on the Beach) and plays (Bombay Nights), a novelist, star and co-producer in two award winning TV series (Goodness Gracious Me, The Kumars at No. 42), received the prestigious Betty Task Award for her first novel, Anita and Me. In presenting Syal with the prestigious Media Personality of the Year Award, the Daily Mirror deputy editor, Tina Weaver, said: 'Using literature, laughter and some sharp social observation, Meera has brought the lives of Asian women to the foreground and inspired us all to rethink the way we view Asian culture'. As writer of the film East is East comments:

'Everyone thinks it's now hip to be Asian, but Meera really started the ripple. People forget that she has been around and working for years. I remember her doing stand-up when I was at drama school and thinking it was great that not only was an Asian face doing stand-up, but an Asian woman. '(Rubin, 1999)

In The 200 Richest Asians 2003, Eastern Eye notes that 'creative industries' have provided innovative and new businesses for British South Asians. Of the nine businesses profiled by the magazine article, 'A New Breed', seven were in the 'Cultural and Leisure' industrial sector. Of these nine entrepreneurs, the three women were all in leisure or culture-oriented businesses. One had set up a British Asian dance academy, an ayurvedic health food business, and the third a beauty cosmetic business.

Census figures show that South Asian women are fast catching up with South Asian men in the category of Leisure and Personnel Services. Indeed, in the case of Indians, more women $(2,837)$ than men $(2,251)$ are represented in this sector. Pakistani women are also well represented (735) although they are fewer than Pakistani men $(1,175)$, with a gender gap evident only in the case of Bangladeshis (111 women compared to 271 men). In total, 7,380 South Asians work in Leisure and Personnel. As we show in detail below, a further 32,685 (!) Asians work in Culture, Media and Sports. The media is fast becoming an attractive option for young South Asian graduates. The 2001 UK Census reveals that in the category of Culture, Media and Sports there are 13,335 Indian men and 10,847 women; 4,546 Pakistani men and 2,310 women; 1,045 Bangladeshi men and 602 women.

There is thus a subterranean South Asian economy of self-employed individuals and SMEs, some visible on the streets of Britain (South Asian owned corner shops, newsagents or delicatessens, taxi drivers), some less visible since they are located in offices (in the case of professionals), back streets (in the case of manufacturers) and behindthe-scenes in the public sphere of cultural, creative and media industries. This leads to the substantive question we seek to address here. What goes on beyond the media glitz and glamour? What motivates British South Asian women entrepreneurs operating in the cultural economic fields beneath the mainstream's radar screen?

\section{BRITISH ASIAN WOMEN IN THE CULTURE AND MEDIA INDUSTRIES}

The census figures indicate that Asian women's participation in self-employment is possibly higher than average (Dhaliwal, 2000; Carter, Anderson and Shaw, 2001). 
Within the media industry, women are individually self-employed, not part of a family firm. Nevertheless, their clustering appears to have led to the creation of a niche, an emergent ethnic enclave economy, though few women are prominent enough to be recognised by a wider Asian and general public. The argument presented here is that the ethnic enclave grew and expanded over three generations of women and that it went through three complimentary processes: (1) expanding networks, within and beyond the ethnic enclave; (2) increasing complexity and specialisation; (3) several ideological shifts: from (a) a focus on the revival of ethnic 'culture' in the diaspora, to (b) a struggle to transcend being stereotyped and slotted into an 'Asian'-only role rather than a recognition of a more universal professionalism; and (c) finally, to a positive exploitation of the growing diaspora South Asian consumer market. These latter shifts to some extent have paralleled the move between migrant generations of women. In addition, Basu has argued elsewhere (forthcoming) that the growth of the enclave of South Asian women in the culture industries represents a case of 'mixed embeddedness', in relation to enhanced symbolic capital afforded by ethnic networks and enhanced opportunities that opened up in the wider economy.

The case study presented below is based on interviews conducted by Basu with three generations of Indian, Bengali, Gujarati, Sikh Punjabi, Pakistani and Bangladeshi women either working or retired from careers in music, dance, theatre, and media, working in several large British cities: London, Coventry, Manchester, Luton and Birmingham. ${ }^{11}$ Of the 14 women working in the media, all except three were in their early 20 s to early $40 \mathrm{~s}$. They work(ed) in television, music, and radio, as producers, presenters, research assistants, directors and journalists. The remaining ten women interviewed in this cohort were in various sectors of the creative and culture industries: part-time dance and music teachers, a semi-professional rapper, a fashion designer, a wedding and party planner and the owner-founders of dance and performance development agencies, troupes and charities.

Most of the women classified themselves as middle-class. With the exception of four women, all possessed at least two years of further or higher education, the majority a bachelor's degree, three a postgraduate qualification. Among the 'pioneers', most women came from or had married into professional and entrepreneurial families. Those from more modest backgrounds were often the first women in their families not only to obtain a degree, but also to pursue an independent career outside traditional fields of employment and self-employment. These women tended to be younger, in their early twenties to late thirties.

1122 face-to-face interviews and two telephone interviews were undertaken over the spring and summer of 1999, 2003, and 2006. Interviewees were located through snowball sampling, beginning with Basu's friends whose own experiences had inspired the study, and via the editors and producers of South Asian Times, Eastern Eye magazine and the BBC Asian network. Basu's 'non probability purposive sample' included a focus group of four women in 1999, all of whom worked in the media and broadcasting industries.

REMI 2009 (25) 3 pp. 53-77 


\section{The Pioneers: Community and Respectability}

Our analysis reveals that motivation, entrepreneurial success, type of business, challenges and opportunities faced by South Asian women can be viewed as a process taking place over two and a half generations, starting with what we call the 'pioneers', now in their early 40 s to late $60 \mathrm{~s}$. Their role has been first, to invent and reconstitute South Asian culture in the diaspora as an aesthetic genre, and second, to shift it away from its traditional domestic setting into the public arena. Their pioneering role lay in building economic and creative realms that expanded the cultural horizons of British as well as diaspora South Asian identity, culture and politics. Their initial involvement in radio, television, music, health/beauty, and dance in the late 1970s and early 1980s began overwhelmingly as voluntary and community work, arising from cultural, familial and community-building concerns. Over subsequent decades this developed into paid work as freelancers (peripatetic dance teachers, broadcasters and journalists), health and beauty manufacturers or retailers, and founders of charities, development agencies and consultancy businesses centred around the performing arts, storytelling, theatre and dance. Moving from voluntarism, they developed entrepreneurial activities that provided a significant number with a steady profit, income, and social prestige.

With the exception of two women, all the pioneer generation came from professional and managerial backgrounds. They were all married, only one couple remained childless, and the majority were arts or science graduates from India or East Africa. Six of the eight had spouses who were professionals, managers or businessmen. They began as volunteers: teaching Hindi or Gujarati, sponsoring or teaching dance, organising community associations and performances to promote 'South Asian', 'Sikh' or 'Indian' culture, lobbying for public access and fair representation in local and national broadcasting, or researching and broadcasting programmes for community radio.

Their careers often began for deeply personal reasons, arising from the experiences of migration and institutional racism. But a central theme reiterated in the interviews was their felt desire to preserve Asian culture, whether regional, linguistic, or religious, in the face of alluring 'Western' TV 'gora' ('white') culture, which had captivated their children and led them to reject their own cultural and religious traditions of music, arts and culture. The pioneers acted out of fear of 'cultural loss', of abandoning a 'rich heritage'. They had to convince sceptical husbands to give them the freedom to work, against the gaze of a disapproving community that saw art and music as merely a source of cheap titillation. This led them to promote Asian entertainment as 'high' culture: classical and folk dance rather than popular music and Hindi film dancing. Playing music, dancing, and practising other Indian art forms were held in high familial esteem, as long as they were combined with marriage and education. The discourse was one of 'respectability' that underlined 'ethnic' religious and regional values, and excluded disreputable connotations.

The women distinguished themselves from other South Asians: by contrast to others, their careers were not viewed by family or friends as a transgression of social and moral codes. At the outset, especially, expressions of disapproval and prejudice from other community members rather than access to finance or networks constrained their endeavors. 
Dance was associated with entertainment, immorality, 'spoiling' the girl's virtue. This differed depending on what you were, Sikh or South Indian or Muslim, but by and large, it applied to all of them.

'But I was not just an entertainer, I came from a family in which playing music and learning bharat nathyam is an accomplishment.'(Dance teacher and a pharma-

One woman described the resistance to her voluntary scheme for young Asian girls at a local radio station, to learn broadcasting technical skills.

'They somehow felt that even me, a well-respected women with a young daughter myself, could not buffer the corrupting influence of black people and their music on their daughters. '(Broadcaster and journalist)

Because the pioneers were operating in their own communities with businesses that required little start-up costs, none used external sources of finance. All began with their own money, obtained through informal rotating credit associations or their husbands. This may account for their more pronounced condemnation of community conservatism, rather than the institutional racism one might have expected. While most said their husbands did not mind their late evenings, public visibility, or erratic schedules, they were the target of community gossip. Exceptionally, one woman, a beautician who often attended late night pre-wedding mehndi (henna) rituals, was verbally abused by her husband for acting immorally and reported to the V.A.T. officials, for tax evasion. Eventually she left him to run a successful beauty parlour with her daughter while the latter was pursuing her musical career.

For the pioneers, success was hardly ever framed in purely economic terms. Their main concern was the next generation (see also Tran and Nguyen, 1994). But importantly, personal aspirations coincided with public funding opportunities to take 'heritage' arts beyond the community and create artistic space for Indian dance in the mainstream (Kaur and Terracciano, 2006: 346). Here, the pioneers' motives and subsequent involvement were set against the resurgence of community-specific, culture-focused institutions in the 1970s.

This enabled them to turn their sustained community involvement and particular expressive cultural form - dance, performance, story telling, local community plays, community radio shows - into broader ideas of cultural marketing and services. They responded to market demands, incorporating a variety of South Asian and non-South Asian styles, such as hip hop or salsa, into dance or music. One entrepreneur extended her informal wedding party planning by importing saris and other accoutrements for Punjabi weddings on her bi-annual trips back home. In the 21 st century, she provides a comprehensive wedding planning service, from booking the priest to catering and flower decoration. Her work has taken her all over Britain, to Canada, India and Malaysia.

The women's careers point to a 'postmodernist' work interpretation that makes no clear-cut distinction between self-employment, informal, and paid employment, freelancing, and volunteerism - in several interrelated niches. 'You can't just say what is 
creative, my mum was creative in the kitchen for years, but is that registered in government reports?' 'I think it is an artificial boundary to say IT versus Media versus music, they are all interrelated.' 'Well it doesn't account for the way my business developed because I was doing part-time work, volunteering to teach, trying to get grants from the Arts Council and working part time.'

During the start-up period of their businesses, a significant number held publicsector jobs: teachers, local authority workers, community workers, court translators. One woman was a self-employed professional. This not only provided a secure income, it often financed their start-ups. Work-related resources also expanded social networks beyond immediate friends and family. They intentionally tapped their and their husbands' contacts to garner information, contacts and contracts for their burgeoning cultural activities. Contacts with local academics and race-relations professionals enabled one pioneer to lobby her local $\mathrm{BBC}$ radio programming unit, and she went on to serve as an advisor for a Commission for Racial Equality Report on ethnic minorities and the media, helping to establish practice guidelines sensitive to 'minority' issues. She ran a regular spot on a local black community radio ethnic programme. Another established her network over several years as a bharath nathyam teacher, while working for the municipal authority. Her cultural shows and reputation as a dancer created links to the local Arts Council. Her dance troupe emerged 'organically' out of the cultural needs of the Asian community, and a drive for legitimisation and recognition by British culture and arts. She formed a dance company that trains dancers, coordinates dance programmes, and advises administrative staff on grant applications. Most recently, she was part of a delegation from the Ministry of Culture and Sports to a UNESCO conference.

The pioneers did not prioritise economic success only. Many worked towards integrating, mainstreaming or developing their cultural products to bring prestige, support systems and developmental resources to British South Asian cultural workers. Pioneers had to overcome religious and regional rivalries between South Asian groups in their attempts to carve out entrepreneurial niches, not only for themselves but for younger British South Asians in the arts, broadcasting and dance. One entrepreneur recalled the cultural politics of programming. A woman who made current affairs and music programmes, she took up some of these communal criticisms with the radio authorities in order to demand the need to recruit 'more people from all parts of India and Pakistan, to represent what an Asian radio programme, or for that matter, Asian culture, is.' Despite initial community protestations, and resistance from White run radio stations, she managed to turn the problem into an opportunity, rather than being dismissed as 'just an Asian women who should just be glad to have the job, and [should] sit down and shut up.'

By engaging with the public and cultural realm as a central site for reproducing, sustaining and reformulating various diasporic cultural practices, pioneers exhibited some characteristics of 'traditional' modes of Asian business success, and not others. They differed from women whose presence in business is part of a cohesive family strategy, or who are motivated by labour market disadvantages. Their aspirations embraced the needs of their children and the local community, and they often began with voluntary involvement in community-based organizations. Throughout the interviews it appeared that the value of their work was measured by aesthetic and social yardsticks, rather than solely 
by earnings. Their role was that of cultural navigators moved by a deep sense of social responsibility. They appropriated dominant discourses of motherhood and domesticity to justify their independent activities, rather than flouting them. They established music and dance workshops for deaf, poor and marginalised children. They provided community culture services and artistic products, free or for nominal pay.

The three 1970s pioneers in radio broadcasting challenged homogeneous representations of Indians, Pakistanis and Bangladeshis. One woman joined the Black Media Workers' Association, a pressure group encouraging community involvement by establishing video groups and attracting government grants to improve independent black media, and monitor representations of race on television. Her efforts and the campaigning of two of the other pioneers on a variety of political issues surrounding race and assimilation pre-dated more formalised institutional agendas and public policies centring on access and representation of excluded social groups (Malik, 2002). In the 1980s these saw the introduction of a number of ethnic programme units and training schemes. The 1990 Broadcasting Act obliged terrestrial television to outsource at least twenty five per cent of their programming. This led to an upsurge in single project-led commission structures, resulting in a workforce taking on freelancing, part time and short term contract work rather than salaried employment (Malik, 2002). This institutional change affected the experiences of the remaining two generational cohorts in the media.

\section{The Second and Third Generation: the Elaboration of the Enclave}

The expanding opportunities for 'ethnic' programming meant that for women wanting to freelance or start their own businesses in the media in 1980s and ' 90 s there was a greater mix of motivating factors than for the pioneers. University graduates in their mid-30s or -40 s cited being blocked in their salaried employment as the primary reason for taking up self-employment. Women working in broadcasting typically moved frequently between employment (on short-term contracts) and freelancing, from pitching programme ideas for commissioning, to writing for radio, television, print or the internet, editing, reporting, news reading and producing programmes simultaneously. They came to the media at a time of revived dynamism and interest in black cultural production and arts, with public institutions and broadcasting bodies such as Channel 4 and BBC making special minority provisions, training and cultural diversity in-house requirements.

Of the six women interviewed in this cohort, all received their training in editing, researching, and production through 'ethnic', 'black' or multicultural departments explicitly formed to train and recruit black people, explore black issues and create black specialist units, in large part the result of lobbying efforts by black and Asian communities and organizations formed during the 1970s and '80s. Before that, women's initial entry arose from involvement in the 1980s Black workshop movements in video and film. Even in the absence of family role models, trainee internships with community radio stations or local workshops in libraries or colleges provided basic skill-training in broadcasting and production, which spurred their media career.

Media recruitment networks ranged from friends and university contacts, adverts in the 'ethnic' radio and press, involvement in university social events, and college radio 
ethnic broadcasting. One entrepreneur had helped a friend mae a government-funded community project-video about Asian suicides.

Women's careers developed in the context of rapid economic restructuring. Their decision to go freelance or form their own production company was moved by deregulation and technological innovations, leading to fragmented niche markets and market-orientated public broadcasting. The 1990 Broadcasting Act made women's work position more precarious, frustrating and demoralising, after years of working on ethnic programmes. Unlike the first generation, they wanted to be respected for their professionalism rather their expertise on:

'Asian culture, Asian social issues, Asian social problems, Asian prostitutes, Asian domestic violence (...). But if I wanted to give a more informative and complex account, that was knocked down too because it wouldn't interest most viewers because it was too 'partisan'or 'political.'

They wanted to escape the ethnic programming niche, to be eligible for management positions, to be able to address meaningful change in content, programming, format or scheduling (Cottle, 2000). The main barrier was exclusion from mainstream job opportunities. At the Race in the Media Awards organized by the CRE in 2000, BBC DirectorGeneral, Greg Dyke confirmed this imbalance: 'Although we have met the eight per cent target [of ethnic minority employees] for all our staff, in management roles that figure comes down to less than two per cent. The top of the BBC is very white.'

Rigid pigeon-holing constrained women's career development. Repeated attempts to produce 'real' stories such as revisiting the 1981 uprisings in the aftermath of the Stephen Lawrence enquiry, or examining the experience of colonisation from the colonised point-of-view, were dismissed by management. This, coupled with the strains of working unsociable hours and forfeiting marriage or partnerships, motivated some women to seek regular salaried employment with more job security in the hope that by building solid reputations over time, they would be better placed to propose, develop and present favoured projects. After years of successful careers, some women yearned to return to more traditional gender relations. One woman commented that, 'as you get older, you just want the very same shit you fought against for years - a house, a husband and free time.' Others, however, felt that self-employment became a viable option in response to restructuring. One woman quit a salaried job, anticipating the inevitable downsizing in the industry. Those who tended to favour freelancing had families, sometimes extended, with family incomes, so money earned was not their only consideration. Others feared that too much time off would put them out of the 'loop.'

Work ambition stemmed not only from their own personal aspirations but from familial expectations that success, recognition and financial independence were framed through work. To legitimise working in a relatively 'unconventional' sphere of Asian economic activity, women deployed familial symbols and tropes of success for family and friends. Parents and husbands complained of the unpredictable hours of work, but as a music journalist and DJ told me, 'I know it was really about me, a young, unmarried Gujarati girl covering music; going to pubs and clubs. It wasn't so much they didn't trust me, but it wasn't much of a sell to prospective future husbands.' 


\section{The Third Generation: Growing South Asian Confidence}

By contrast to earlier generations, the youngest group to enter the culture industries, in their early 20 s to 30 s, were almost unanimous in their conscious and determined decision to carve out a career in the media, formalized by their degrees, and formed in the context of increased British South Asian cultural visibility in Britain. Unlike the pioneers, motivated by worries about the effect of western culture on their children (Trivedi, 1984), growing up in a Britain marked by a paucity of Asian images and role models projected on mainstream programming, entry into journalism, advertising, PR, community and private broadcasting for this youthful cohort was not so much a rejection of parental culture but a response to their experiences as British born and bred, yet South Asian ('Indian', 'Muslim', 'Sikh', 'Punjabi', 'Bengali', 'Gujarati').

The indication is of a growing enclave economy: 'I see so many young Asians wanting to do something in the media - write, produce, whatever, and they feed off each other. Somehow they don't have the hang-ups we used to.' 'Our girls are so smart these days they can slip in and out of family and work so well.' An independent TV producer made the distinction between herself (in her early 20s) and her sister, 10 years older, who had broken away entirely. Whereas her sister felt she had to be 'either Indian or English,' for her being British meant 'melding with Asian culture.'

The youngest cohort of women work in a broader spectrum of media industries: radio, television, print, web, live events, satellite, cable, advertising, marketing and music. These thrive on the visibility of Asian cultural products and consumer markets and celebrities in the public sphere. Not only talent or demand for exotica (Hutnyk, 2000) ) $^{12}$, but unprecedented ethnic minority media growth underpins the enclave: 18 dedicated TV channels, six commercial radio stations, publishers and websites, all seek to extract advertising for the two million-strong British Asian consumer tastes, over 50 per cent under the age of 40 . While some view this deregulation as damaging, others welcome its opportunities.

Among the most youthful entrants, market labour disadvantage was not the compelling reason for self-employment, even if this apparently contradicted their own experiments in entrepreneurship. Though they peppered the interviews with references to 'having to work thrice as hard because I am a British Asian,' 'not being taken seriously because I am the pretty exotic thing in the room,' 'not having the contacts that a lot of the public school boys in the business have,' disadvantage did not figure prominently in their response to why they went into self-employment and business. The increased need to multi-task short-term contracts, project-based employment, investing time and money in building networks, were rarely perceived as arduous or exploitative but more as necessary and even enjoyable. Common to these younger women was their conscious drive to carve out a somewhat unconventional career trajectory that by necessity required multi-tasking, voluntarism, internships, and different jobs and forms of payment. For this generational cohort, there was less anxiety about the institutionalised processes that cast them into 'ethnic' or community programming, or demanded more of them because of less manpower and resources than non-ethnic departments. In part this may be because oppor-

12 See for example the discussion of Asian Kool in Sanjay et al., 1996.

REMI 2009 (25) 3 pp. 53-77 
tunities in the media have expanded so dramatically: satellite and cable television and radio, the internet and other forms of the new and ethnic media, advertising and marketing, have prised open the cultural industries. In part this is because cultural workers buy into their own 'permanently transitional' work, in Angela McRobbie's (2001) words, endorsing in practice a working culture that blurs the distinctions between work and leisure, single projects and multi-tasking, paid and unpaid work. For many, being stereotyped as Asian no longer mattered. As a freelancer for BBC Asian network explained, 'I'm not bothered... I have become thick-skinned and I want to use my experience here to set up my own record label' (Radio producer).

Unlike previous generations, most third generation women held degrees from the 'new' universities in Communications and Media Studies, often with an emphasis on psychology or business. For all the women in the youngest age cohort volunteering at local and college radio stations, attending local workshops, involvement in student union activities, newspapers or college radio, networking and (unpaid) work experience built up their resumes for good media jobs. They stressed college friends, colleagues and industry co-workers, as well as their own determination, but rarely a college counsellor or family friend as important sources of motivation, information and networks.

\section{CONSTRAINTS ACROSS THE GENERATIONS}

Regardless of their time in the industry, all the women related stories of their disadvantaged position in the media, from access to finance and commissioning to the exclusiveness of networks at higher echelons. This impelled them to seek new opportunities or develop resources for other Asian women facing a glass ceiling: training, mentorship and conferences (Pollard et al., 2005). The most pressing problem for all generations was access to commissions, grants, business advice and support. For women seeking contracts in large media institutions such as Channel 4 or the BBC, a common complaint was that commissioners tended to evaluate their capabilities on the basis of their ethnicity and gender. Some spoke of nepotism in freelance contracting, making it harder to enforce equal opportunities policies. For others, deregulation meant career and business opportunities. Entrepreneurs experienced common multiple hurdles: misinformation, lack of access to grant awarding body members, 'lost paperwork'. But despite the continued ghettoisation felt by several women, broadcasting deregulation presented opportunities as well as constraints, as a journalist for website and Asian print newspaper explains: 'It's not like there is only terrestrial TV. With satellite and cable, and the internet we can make our own opportunities, I know I have'.

Incorporated into women's career strategies was a clear view of 'what needs to be done' to be successful, summed up as entrepreneurship, freelancing and voluntarism. Several women developed programmes for young Asian women entering the swelling market for 'diversity' cultural programming on mainstream television and radio. They set up training workshops in fields from dance to broadcasting. What emerges is a sense of constant improvisation, reskilling, innovation and movement inside and outside a reconfigured marketplace, as technological innovations gather pace. In an enormously expanding British media industry, the production of specialist magazines and the move away from 
terrestrial television have create new openings for self-employed designers, performers, actors, advertisers, journalists and other media entrepreneurs or cultural intermediaries. These tap symbolic and cultural capital rather than specific 'ethnic' resources.

Networks across sectoral lines were deliberately used for promotion and marketing products in the leisure and beauty industries. For all those involved, their contemporaries, mentors or contacts in the community were important for gathering information about possible business opportunities. For women in the media vying for documentary programme opportunities, friends, relatives and the 'ethnic' press are important sources of programming ideas.

As in previous generations, internal fractures affect the youngest cohort. Night clubs exorbitant insurance costs were blamed by one entrepreneur on the reputation Asians had acquired for fighting amongst themselves. There was still a good deal of bias against women entrepreneurs within the community: 'basically being an Indian woman in charge of a night club did their heads in (...)' There were still difficulties convincing parents that clubs were both a viable money-making scheme and a way to provide an important cultural space for young British Asians.

Women also spoke of the sometimes hostile reception of their success. According to one female rapper, when she first 'stepped up to the mike,' other men in the cipher would first ignore her. Then, when she freestyled (rapped extemporaneously over music) they would congratulate her and give her the mike, and as soon as she got some local fame, other British South Asians lambasted her for wanting to be 'Black', and the Black MCs envied her visibility as a female Asian MC. Against this type of experience she consciously works with an entourage of young women who help her run her affairs, recruit dancers, set up interviews, and so forth.

Women cultural practitioners are creating and distributing cultural texts and products - in comedy, films, journalism, fashion or design. Social networking is marked by mutual desire to sustain social and professional relationships outside work - in cafés, bars, and other media haunts, to endorse each others' programming ideas, and advise, research or recommend their work to others. At times, however, professional jealousies and competition mar these relations of mutual support, with allegations of using looks or sexual availability as competitive advantage.

Enclaving in certain niche markets compounds this competition. But despite such rivalries and jealousies, many women are supported through workshops and connections. Some work to influence policies and practices in the private and public sector funding of arts and creative industries, while others are involved in institution-building, organising awards, formal alliances, and forums where British South Asian women can meet, network, share ideas, form alliances and find support. Against the odds, the enclave is growing, with emphasis not just on money and personal prestige, but also on philanthropy, advocacy, education and civic mindedness, as guiding and organizing principles. 


\section{CONCLUSION}

In 2003, Gurinder Chadha's sixth film, Bend it Like Beckham, made her the director and writer of the highest grossing British-financed, British-distributed film ever (some $£ 11 \mathrm{~m}$ in ticket sales). Her financial success was matched by international critical acclaim. She has won eleven film awards, across the globe. Despite significant constraints, British South Asian women in the culture industries cannot be construed as marginal or invisible in an industry promoted by the Arts Council to the tune of $£ 12 \mathrm{~m}$ per annum in 2005, in order to:

'(...) ensure that a larger number of talented high-flyers in cultural organisations will be able to develop commercial and business leadership skills, encourage the leadership talents of leading ethnic minority figures in the arts, and create new opportunities for business-arts collaboration.' (Rt Hon Gordon Brown MP, Chancellor of the Exchequer, Budget Statement 2005).

In 2003, Eastern Eye changed the title of its magazine to 'Success' and added listings of the 20 richest Indian-based magnates and 20 richest (South) Asian American businessmen to the British list. In 2006, in a further shift, the magazine abandoned its listing of the 200 richest Asians in Britain in favour of a focus on Asian 'power' and 'influence' as well as money. The editor, Hamant Vermant, explains that 'success cannot be measured purely by wealth' (Success, 2006: 11). Spinder Dhaliwal, associate editor, added that 'this year we look at the power players and not just the rich players' (ibid.: 12). In addition to the usual listing of the 20 richest Indians and American South Asians, the richest British South Asians were reduced by the magazine to a mere 20 (the poorest of whom is worth around $£ 88$ million). Other 'entrepreneurs' are listed by sector: the Media, Law, Fashion, IT (especially web-based companies), Property (including hotels and car dealerships), Food, and Sport, and include well known personalities like Shami Chakrabarti, director of Liberty, Imran Khan, family lawyer in the Stephen Lawrence case, or Amir Khan, the young featherweight boxer, who are not necessarily multi-millionaires at present. At the same time, however, Barclays issued a report of the richest Asians in Britain (Dhaliwal, 2006b). The fascination with wealth and success is thus a topic that refuses to die.

Ethnic enclave economies provide the social, symbolic and cultural capital for the present generation of young British South Asians women in the media. As new audiences are built, so too is the likelihood that some will feature in the list of Britain's 200 Richest South Asians. But their inclusion, we have proposed here, hides as much as it reveals. It disguises the wide range of SMEs and self-employed professionals which sustain a whole industry.

Hidden beneath the public fame of Asian women who win awards and critical acclaim, this paper has proposed, is a subterranean ethnic economy that encompasses 
many other vibrant contributors to British arts, culture, and the media. ${ }^{13}$ While none of the women were millionairesses at the time they were interviewed, one has made it into the list, several are nationally recognized, and others are mentors, rivals, competitors, and comrades in a loosely affiliated nascent feminised entrepreneurial enclave that includes, but is not limited to, visible markers of success - money, recognition, prestige.

While not all the women are 'successful' according to conventional measures of turnover and profit, the emergent enclave of Asian women in the cultural and creative industries is demarcating (as well as responding to) a market that only 30 years ago defined them narrowly as 'traditional' wives, mothers and home-makers or exploited manual workers. Their rise is predicated on an emerging enclave economy of British South Asian cultural products in which visible stars are just the tip of the iceberg.

\section{References}

BACHKANIWALA Darshan, WRIGHT Mike and RAM Monder (2001) Succession in South Asian Family Businesses in the UK, International Small Business Journal, 9 (4), pp. 15-27.

BAINES S. and WHEELOCK J. (1998) Reinventing Traditional Solutions: Job Creation, Gender and the Micro-business Household, Work, Employment and Society, 12, pp. 579-601.

BARTH Frederik (1963) Introduction, in Frederik Barth Ed., The Role of the Entrepreneur in Social Change in Northern Norway, Bergen, Universitetsforlaget.

BASU Dipannita (forthcoming) South Asian Women in the Creative Industries: A Generational Perspective, under consideration.

BASU Dipannita and WERBNER Pnina (2000) Bootstrap Capitalism and the Culture Industries: A Critique of Invidious Comparisons in the Study of Ethnic Entrepreneurship, Ethnic and Racial Studies.

BERESFORD Philip and BALAKRISHNAN Paran (2000) Britain's Richest Asians, Eastern Eye, London, Ethnic Media Group.

BHACHU Parminder (2004) Dangerous Designs: Asian Women Fashion the Diaspora Economies, London, Routledge.

CARTER S., ANDERSON S. and SHAW E. (2001) Women's Business Ownership: A Review of the Academic, Popular and Internet Literature, London, Small Business Service Research Report RR002/01.

Census UK (2001), http://www.statistics.gov.uk/downloads/census2001/National_report_EW_ Part1.pdf.

COTTLE Simon (2000) A Rock and A Hard Place: Making Ethnic Minority Television, in Simon Cottle Ed., Ethnic Minorities and the Media: Changing Cultural Boundaries, Philadelphia, Open University Press.

DAWE A and FIELDEN S. (2005) The Experiences of Asian Women Entering Business Start-ups in the UK, in Fielden S and Davidson M. Eds., International Handbook of Women and Small Business Entrepreneurship, Cheltenham, Edward Elgar.

DHALIWAL Spinder (2000) Asian Female Entrepreneurs and Women in Business - an Exploratory Study, Enterprise and Innovation Management Studies, 1 (2), pp. 207-216.

13 This includes, for example, the first Muslim columnist for The Sun (Baig), BBC Director of foreign current affairs, Ruhi Hamid, Sudha Bhuchar and Kristine Landon Smith, founders of Tamasha Theatre Company, Piali Rai (OBE) founder of Sampad and OBE and honorary PhD and many others. 
DHALIWAL Spinder (2006a) A Fresh Way to Tell an Old and Familiar Story, in Success 2006, Eastern Eye.

DHALIWAL Spinder (2006b) Asian Entrepreneurs in the UK, Report written Barclays Bank and disseminated as a press release under the title Michael Hanna, Research shows that UK Asian wealth has increased by 69 percent, in Goarticles.com.

DHALIWAL Spinder and ADCROFT Andy (2005a) Sustainability and Ethnic Minority Businesses: An Examination of the Asian Business Sector in the UK, in www.asiaentrepreneurshipjournal. com

DHALIWAL Spinder and ADCROFT Andy (2005b) Title as above, Journal of Asia Entrepreneurship and Sustainability, 1 (1), in www.asiaentrepreneurshipjournal.com/currentedition.html.

Eastern Eye (2001, 2002, 2003, 2006) Britain's Richest Asians, London, Ethnic Media Group.

DHALIWAL Spinder and ADCROFT Andy (2003) Success 2003: The Young One, London, Ethnic Media Group.

EDMUNDS June and TURNER Bryan (2002a) Generations, Culture and Society, Milton, Keynes, Open University Press.

EDMUNDS June and TURNER Bryan Eds. (2002b) Generational Consciousness, Narrative and Politics, MA, Rowman and Littlefield.

HUTNYK John (2000) Critique of Exotica: Music, Politics and the Culture Industry, London, Pluto Press.

JANJUHA-JIVRAJ S. (2003) The Sustainability of Social Capital within Ethnic Networks, Journal of Business Ethics, 47, pp. 31-43.

JANJUHA-JIVRAJ S. (2004) The Impact of the Mother during Family Business Succession: Examples from the Asian Business Community, Journal of Ethnic and Migration Studies, 30 (4), pp. 781-797.

JANJUHA-JIVRAJ S. (2005) Succession in Asian Family Firms, Basingstoke, Palgrave.

JANJUHA-JIVRAJ S. and WOODS A. (2002) Succession Issues within Family Firms: Learning from the Kenyan Experience, International Small Business Journal, 21 (1), pp. 77-94.

JONES T., ABBAS T. and RAM M. (Forthcoming) Ethnic Enterprise in an Urban Context: The Case of the Independent Restaurant Sector in Birmingham, in Boddy M. Ed., Cities, Competitiveness and Cohesion, Bristol, Polity Press.

KAUR Raminder and TERRACCIANO Alda (2006) South Asian/British South Asian Performing Arts, in Nasreen Ali, Virinder S. Kalra and Salman Sayyid Eds., A Post colonial People: South Asians in Britain, London, Hurst Publishers, p. 343.

KALRA Virinder S. (2000) From Textile Mills to Taxi Ranks: Experiences of Migration, Labour and Social Change, Aldershot, Ashgate.

LEFEBVRE Henri (1991) The Production of Space, trans. Donald Nicholson-Smith, Oxford, Blackwell.

LIGHT Ivan and ROSENSTEIN Carolyn (1995) Race, Ethnicity and Entrepreneurship in Urban America, New York, Aldene de Gruyter.

LYON Michael and WEST Bernice J.M. (1995) London Patels: Caste and Commerce, New Community, 21 (3), pp. 399-420.

MALIK Sarita (2002) Representing Black Briton: Black and Asian Images on Television, London, Sage.

MCROBBIE Angela (2001) From Holloway to Hollywood: Happiness at Work in the Cultural Economy, in Paul du Gay and M Pryke Eds., Cultural Economy: Cultural Analysis and Commercial Life, London, Sage.

METCALF Hillary, MODOOD Tariq and VIRDEE Satnam (1996) Asian Self-employment: the Interaction of Culture and Economics in England, London, Policy Studies Institute.

MIRCHANDANI K. (1999) Feminist insight on Gendered Work: New Directions in Research on Women and Entrepreneurship, Gender, Work and Organisation, 6 (4), pp. 224-236. 
OGBOR J.-O. (2000) Mythicizing and Reification in Entrepreneurial Discourse: Ideology-Critique of Entrepreneurial Studies, Journal of Management Studies, 37 (5), pp. 605-635.

POLLARD E, BARKWORTH R, SHEPPARD E and TAMKIN P. (2005) Researching the Independent Production Sector: a Focus on Minority Ethnic Led Companies, IES/Pact/UKFC, in http://www.employment-studies.co.uk/summary/summary.php?id=pactukfc.

RAM M. (1994) Managing to Survive-Working Lives in Small Firms, Oxford, Blackwell.

RAM M. and CARTER S. (2003) Paving Professional Futures: Ethnic Minority Accountants in the United Kingdom, International Small Business Journal, 21 (1), pp. 55-71.

RAGHURAM Parvati (2003) Fashioning the South Asian Diaspora: Production and Consumption Tales, in Nirmal Puwar and Parvati Rghuram Eds., South Asian Women in the Diaspora, Oxford, Berg, pp. 67-86.

RUBIN Gareth (1999) Interview with Meera Syal - Meera's Image, The Independent, December 19 Sunday, pp. 11-12.

SHARMA Sanjay, HUTNYK John and SHARMA Ashwani Eds. (1996) Dis-Orienting Rhythms: the Politics of the New Asian Dance Music, London, Zed Books.

SCHMITZ Hubert and NADVI Khalid (1999) Clustering and Industrialization: Introduction, in Industrial Clusters in Developing Countries, special issue of World Development, 27 (9), pp. 1503-1514.

THANDI Shinder S. (2006) Brown Economy: Enterprise and Employment, in Nasreen Ali, Virinder S. Kalra and Salman Sayyid Eds., A Post colonial People: South Asians in Britain, London, Hurst Publishers, p. 211.

TRAN Thanh V. and NGUYEN Thang D. (1994) Gender and Satisfaction with the Host Society among Indochinese Refugees, International Migration Review, 28 (2), pp. 333-334.

WALDINGER Roger (1994) The Making of a Immigrant niche, International Migration Review, 28 (105), p. 15.

WALDINGER Roger (1996) Still the Promised City? African-Americans and New Immigrants in Post-Industrial New York, Cambridge Mass, Harvard University Press.

WERBNER Pnina (1987) Enclave Economies and Family Firms: Pakistani Traders in a British City, in Jeremy S. Eades Ed., Migrants, Workers and the Social Order, ASA Monographs 26, London, Tavistock, pp. 213-233.

WERBNER Pnina (1990a/2002) The Migration Process: Capital, Gifts and Offerings among British Pakistanis, Second edition with new preface, Oxford, Berg.

WERBNER Pnina (1990b) Renewing an Industrial Past: British Pakistani Entrepreneurship in Manchester, Migration, 8, pp. 7-41 (Reprinted in Judith M. Brown and Rosemary Foot Eds. (1994) Migration: The Asian Experience, Macmillan).

WERBNER Pnina (1999) What Colour 'Success'? Distorting Value in Studies of Ethnic Entrepreneurship, Sociological Review, August. Also to appear in Hans van Vermeulen and Joel Perlmann Eds., Does Culture Make a Difference?, London, Macmillan.

WERBNER Pnina (2001) Metaphors of Spatiality and Networks in the Plural City: A Critique of the Ethnic Enclave Economy Debate, Sociology, 35 (3), pp. 671-693.

WHEELER Ed (1988) Black Gold, paper presented at the International Visual Sociological Association Meeting, Rochester, July. 


\section{APPENDIX 1}

Components of Asian Wealth Generation 1998-2004

\begin{tabular}{|c|c|c|c|c|}
\hline Year & $\begin{array}{c}\text { Asian Wealth } \\
\text { Generated } \\
(£ \text { mill) }\end{array}$ & $\begin{array}{c}\text { High Value } \\
(£ \text { mill) }\end{array}$ & $\begin{array}{c}\text { Low Value } \\
(£ \text { mill) }\end{array}$ & $\begin{array}{c}\text { Share Taken } \\
\text { by Top 10\% of } \\
\text { Wealth Genera- } \\
\text { tors (\%) }\end{array}$ \\
\hline 1998 & 4437.4 & 500 & 2.0 & 60.5 \\
\hline 1999 & 5232.3 & 450 & 5.0 & 54.9 \\
\hline 2000 & 6453.6 & 325 & 6.0 & 48.9 \\
\hline 2001 & 7124.9 & 300 & 6.0 & 45.6 \\
\hline 2002 & 7354.7 & 450 & 8.8 & 43.4 \\
\hline 2003 & 7078.4 & 460 & 4.0 & 44.8 \\
\hline 2004 & 7767.5 & 500 & 4.0 & 45.8 \\
\hline
\end{tabular}

(Source: Eastern Eye 1998-2004); (Dhaliwal and Adcroft 2005: 10) 


\title{
Qui veut gagner des millions? \\ L'entreprenariat des femmes britanniques d'Asie du sud dans les industries de la culture
}

\author{
Dipannita BASU et Pnina WERBNER
}

Les deux cents Richest Asians Magazines 2000, 2002, 2003 illustrent le succès des multimillionnaires britanniques d'Asie du sud par des figures mettant au premier plan des caractères et des traits masculins. Cependant, ce magazine n'hésite pas à dire que de telles réussites individuelles ne représentent que la pointe de l'« iceberg entrepreneurial ». Elles dissimulent l'existence de nombre d'entreprises ethniques concentrées dans certains secteurs économiques et qui peuvent être dirigées par des femmes comme par des hommes. Si les hommes d'Asie du Sud occupaient initialement les créneaux économiques de l'alimentation, du vêtement, de l'immobilier et des technologies informatiques, l'entrée des deuxième et troisième générations de migrants dans les entreprises indépendantes des média et de la culture, inclut un nombre conséquent de femmes. La multiplication des réussites économiques des femmes d'Asie du Sud dans les média, comme la réalisation d'autres grosses fortunes asiatiques, ne peut s'expliquer que par la formation historique d'une enclave économique sud-asiatique dans les entreprises de la culture en Grande-Bretagne, dans lesquelles les femmes jouent un rôle déterminant.

\section{Who Wants to be a Millionaire? Gendered Entrepreneurship and British South Asian Women in the Culture Industries}

\author{
Dipannita BASU and Pnina WERBNER
}

The 200 Richest Asians Magazines 2000, 2002, 2003 construct the success of British South Asian multi-millionaires in images that foreground their masculine traits and characteristics. And yet, this paper argues, such individual success stories are merely the tip of an "entrepreneurial iceberg". They mask the existence of clusters of immigrant enterprises concentrated in particular economic sectors and industries. These may be headed by women as well as men. While South Asian men in Britain initially dominated the food, clothing, property and IT economic enclaves, the entry of second- and third-generation migrants into professional self-employment in the media and culture industries has included a substantial number of women as well. Like other South Asian millionaires, however, to understand the rise of South Asian women media millionaires, the paper argues, we need to look beyond individual success stories to the historical formation of a growing South Asian enclave economy in the culture industries in Britain, in which women play a major role. 


\title{
¿Quién quiere ser millonaria? \\ El empresariado de mujeres británicas de Asia del sur en las industrias de la cultura
}

\author{
Dipannita BASU y Pnina WERBNER
}

Los dos cientos Richest Asians Magazines 2000, 2002, 2003 ilustran el éxito de los multimillonarios británicos de Asia del sur con figuras que valoran a caracteres y rasgos masculinos. Sin embargo la revista se atreve a decir que estos éxitos individuales representan solo la punta del «iceberg empresarial». Disimulan la existencia de numerosas empresas étnicas concentradas en ciertos sectores económicos y que pueden tener a su cabeza tanto una mujer como un hombre. Si los hombres de Asia del sur ocuparon en un primer tiempo ciertos segmentos del mercado como la alimentación, la confección, el sector inmobiliario y las nuevas tecnologías, las mujeres fueron más numerosas cuando la segunda y la tercera generación entraron en las empresas independientes de la información y de la cultura. Solo la formación histórica de una enclave económica surasiática de empresas culturales de Gran Bretaña, enclave en la cual las mujeres tuvieron un papel determinante, puede explicar tanto la aparición de nuevas e importantes fortunas como la multiplicación de éxitos económicos de mujeres de Asia del Sur en los medias. 